Журнал«Герспективита іновації науки»

(Серія«Герагогіка», Серія«Гцихологія», Серія«Медицинв»

№2(7) 2022

УДК 159.9.077

https://doi.org/10.52058/2786-4952-2022-2(7)-980-989

Срібна Оксана Володимирівна кандидат психологічних наук, доцент кафедри безпеки польотів факультету льотної експлуатації та обслуговування повітряного руху, Льотна Академія Національного авіаційного університету (ЛА НАУ), вул. Добровольського, 1, м. Кропивницький, 25005, тел.: (066) 920-50-17, https://orcid.org/0000-0002-1473-9506

Зіміна Юлія Олександрівна магістр психології, старший викладач кафедри психології та соціально-гуманітарних дисциплін, ПАТ "Вищий навчальний заклад" Міжрегіональна академія управління персоналом" Центральноукраїнський інститут, вул. Варшавська, 1, м. Кропивницький, тел.: (095) 745-28-70, https://orcid.org/0000-0003-1309-7254

\title{
ВПЛИВ ГЕНДЕРНОЇ ІДЕНТИЧНОСТІ НА ПРОЦЕСИ НАВЧАННЯ І ПРАЦІ
}

Анотація. У статті здійснюється спроба визначити аспекти ідентичности, що мають вплив на процес взаємодії особистості із іншими. Акцент робиться саме на гендерному аспекті ідентичності, як суттєвому чиннику виявлення ідентичності особистості та їі прояву в процесі комунікації.

У статті представлено результати теоретичного аналізу та емпіричного дослідження процесу поєднання трудової та навчальної діяльності студентами різної статі. Проаналізовано погляди багатьох вчених, які займалися вивченням проблеми гендерної ідентичності в цілому. Так, гендерна ідентичність студентів $€$ особистісною детермінантою їхньої навчальної i професійної діяльності. Оскільки соціально-психологічні фактори можуть зумовлювати і негативне іiі проявлення, то вони виступають стресогенним чинником.

В ході емпіричного дослідження було з'ясовано, що представникам обох статті вдається поєднувати роботу і навчання у вузі, не зважаючи на перешкоди та наслідки. Для жінок праця поширює їхнє світосприйняття, внаслідок цього й здійснюе позитивний вплив на навчальну діяльність. Більшість студентів визначились в тому, що їхня статева ознака не впливає на навчання й оцінювання їхніх знань викладачами. Як чоловіки так і жінки 3 гордістю сприймають власну можливість поєднувати працю 3 навчанням, тому що це свідчить про їхню незалежність та самостійність. Набутий досвід, під час поєднання праці й навчання, надав більш чіткого уявлення щодо обраної професії. Переважно чоловіки вважають, що помилилися у виборі професійного шляху й пов'язують власне майбутнє 3 іншою спеціальністю. Якщо ж негативна, тобто трудова діяльність виступає вимушеним кроком, то негативно сприймається і необхідність водночас навчатися. За результатами опитування випливає, що юнацтву в даному віці легше працювати, аніж навчатись. 
У дослідженні зазначається, що жінки й чоловіки, що поєднують трудову діяльність із навчанням вважають себе дорослими. Водночас, переважно чоловіки, ніж жінки сприймають себе дорослими, сформованими особистостями.

Ключові слова: гендер, психологічні особливості, ідентичність, стресогенність, статево рольова ідентичність, навчальна та трудова діяльність.

Sribna Oksana Volodumurivna Candidate of psychological sciences, Associate Professor, Department of Safety and Environment, Faculty of Forestry Operations and Maintenance air traffic service of the National Aviation Academy of Ukraine (NAU), Dobrovolskogo St., 1, Kropivnitskiy, 25005, tel.: (066) 920-50-17, https://orcid.org/0000-0002-1473-9506

Zimina Yuliya Oleksandrivna Senior Lecturer Department of Psychology and Social Sciences and Humanities PJSC "Higher Educational Institution" Interregional Academy of Personnel Management "Central Ukrainian Institute, 25005, Varshavskaya St., 1, Kropivnitskiy, tel.: (095) 745-28-70, https//orcid.org/0000-0003-1309-7254

\section{THE INFLUENCE OF GENDER IDENTITY ON LEARNING AND WORK PROCESSES}

Abstract. An attempt to define the aspects of ідентичности comes in the article true, that have an influence on the process of cooperation of personality with other. An accent is done exactly on the gender aspect of identity, as to the substantial factor of exposure of identity of personality and her display in the process of communication.

In the article the results of theoretical analysis and empiric research of process of combination of labour and educational activity are presented by the students of different sex. The looks of many scientists, that engaged in the study of problem of gender identity on the whole, are analysed. Yes, a gender identity of students is personality reason of their educational and professional activity. As socialpsychological factors can predetermine and her negative display, then they come forward as a stress factor.

It was found out during empiric research, that to the representatives both the articles succeed to be combined work and studies in institution of higher learning, not having regard to obstacles and consequences. For women labour distributes their perception of the world, hereupon and carries out positive influence on educational activity. Most students were determined in that their sexual character does not influence on studies and evaluation of their knowledge teachers. As men so women perceive own possibility to combine labour with studies proudly, because it testifies to their independence and independence. The purchased experience, during combination of labour and studies, gave more clear presentation in relation to a select profession. 
Men consider mainly, that made a mistake in the choice of professional way and bind actually the future to other speciality.

If negative, id est labour activity comes forward as a force step, then negatively perceived and necessity at the same time to study. On results questioning swims out, that in this age it more easily youth to work, than study. In research marked, that women and men that combine labour activity with studies consider itself adults. At the same time, mainly men, than women perceive itself adults, formed personalities.

Keywords: gender, psychological peculiarities, identity, shyness, gender identity, educational and work activity.

Постановка проблеми. Навчальна діяльність у вищому освітньому закладі істотно відрізняється від навчання в школах. Передусім відмінність полягає у тому, що навчальне навантаження регулює сам студент, а це зумовлює як позитивні, так i негативні наслідки, покладаючи на студента повну відповідальність за найменші хиби в університетському житті. Відтак, не рідкість й істотні труднощі в навчанні, а також пов'язані з ними психологічні стреси.

Звісно, становище студента може істотно погіршитися за необхідності поєднувати навчання із трудовою діяльністю. Кількість обов'язків зростає, а й втім зростає відповідальність.

Гендерна ідентичність (як особистісний конструкт) - важливий фактор світосприйняття, що позначається на ставленні студентів до трудової діяльності.

Навчання виступає провідною діяльністю для студента, який має оволодіти певною професією. Також воно, особливо у сесійний період, виступає й найстресогеннішою діяльністю. Може виникати так званий синдром «вигорання», який блокує бажання навчатись, підвищувати свій професійний рівень. Отже, ми припускаємо, що на стійкість до стресів у студентів, які працюють впливає гендерний фактор.

Метою нашого дослідження є розгляд впливу гендерної ідентичності, на особистісний стрес студентів, що поєднують навчання із працею.

Предметом дослідження - психологічні особливості гендерної ідентичності студентів, що поєднують навчальну й трудову діяльності.

Завдання дослідження:

- з'ясувати та проаналізувати сучасні тенденції дослідження проблематики гендерної ідентичності в студентів, що поєднують трудову й навчальну діяльність;

- $\quad$ розробити опитувальник гендерних особливостей задля з'ясування процесу подолання стресогенного фактору, пов'язаного із специфікою поєднання трудової й навчальної діяльностей.

Аналіз останніх досліджень і публікацій. Поняття ідентичності активно розробляється в сучасній психологічній науці. Н.В. Антонова [1], аналізуючи концепції ідентичності, які висвітлені в зарубіжній психології, виділяє наступні тенденції інтерпретації феномена ідентичності: 
1. І Ідентичність має структурну будову й існує в суб'єктивному часі.

2. Можливе виділення двох аспектів ідентичності - особистісного й соціального. Онтогенетично особистісна ідентичність $є$ вторинною відносно соціальної, бо формується на основі понять, вироблених у процесі соціальної категоризації.

3. І Ідентичність - динамічна структура, вона нелінійно та нерівномірно розвивається упродовж усього життя людини, може протікати як прогресивно, так і регресивно.

4. На поведінковому рівні можливий розгляд ідентичності як процесу розв'язання життєво значущих проблем, причому кожне прийняте рішення робитиме внесок у формування структури ідентичності.

Традиційне тлумачення гендерної ідентичності пов'язується 3 ім'ям Е. Еріксона, який визначив ідентичність як внутрішню безперервність i тотожність особистості [12]. Володіти нею, з погляду Е. Еріксона, означає: відчувати себе, своє буття як особистості незмінним, незалежно від ситуації, ролі, самосприйняття; відчувати минуле, сьогодення та майбутнє як єдине ціле; відчувати зв'язок між власною безперервністю та визнанням цієї безперервності іншими людьми. Він розумів розвиток ідентичності як взаємодію трьох процесів: біологічних, соціальних і его-процесів, причому Его відповідає за інтеграцію перших і других процесів. Результат інтегративної роботи Его чи его-синтезу - конфігурація елементів ідентичності. Схожа конфігурація елементів ідентичності закладена практично в усі визначення поняття гендерної ідентичності.

Сучасні дослідження цього феномену вказують на його складність i багатофункціональність. У вітчизняній психології нині виділилося декілька підходів до визначення гендерної ідентичності.

Гендерна ідентичність, як вважає російський психолог I.С. Клєцина, постає як аспект самосвідомості, що описує сприйняття людиною себе як представника певної статі; одна 3 базових характеристик особистості, що формується в результаті психологічної інтеріоризації чоловічих чи жіночих рис, у процесі взаємодії «Я» та інших, у ході соціалізації [8].

У свою чергу А.А. Денисова визначає це поняття як особливий вид соціальної ідентичності, що співіснує в самосвідомості людини в єдності 3 уявленнями про професійний, сімейний, етнічний, освітній, інший статус. Це продукт соціального конструювання [10].

I.C. Клєцина наголошує: гендерна ідентичність - базова структура соціальної ідентичності, що характеризує людину (індивіда) з точки зору його приналежності до чоловічої чи жіночої групи, при цьому найважливіше значення має те, як сама людина себе категоризує [8].

А.А. Чекаліна [11] відзначає, що діти, які виховуються в культурному середовищі, де чітко визначається й підтримується розподіл сімейних ролей $\mathrm{i}$ функцій, продемонстрували велику поінформованість про перспективи свого розвитку, своєї майбутньої сімейної і соціальної ролі. Діти, які виховуються в 
Журнал«Герспективитаінновації наукиљ

(Серія«Гедагогіка», Серія«Гтихологія», Серія «Медицине»

№2(7) 2022

культурі, де спостерігаються тенденції дозвільного (пермісивного) виховання, демонструють велику індиферентність та амбівалентність у відношенні до своєї статевої приналежності, менший ступінь орієнтації в спілкуванні та діяльності суто на свою стать, менш чітке усвідомлення перспектив своєї майбутньої сімейної, суспільної і професійної ролі з урахуванням статі.

До останнього часу в роботах дослідників, присвячених вивченню гендерної ідентичності, вживалися терміни «психологічна стать» «статеворольова ідентичність» (Ільїн Є.П. [3], Карамушка Л.М., Зайчикова Т.В. [4] I.C. Кон [5], Коломинский Я.Л., Мелтсас М.Х. [6]). Однак навіть близькі, на перший погляд, поняття (як, наприклад, гендерна ідентичність і статево-рольова ідентичність) не є синонімами.

Статева ідентичність, на думку I.В. Романова, - це внутрішня динамічна структура, що інтегрує окремі сторони особистості, пов'язані з усвідомленням і відчуттям себе як представника певної статі, у єдине ціле без втрати їхньої своєрідності [9].

Проаналізувавши зміст та основні характеристики понять гендерна ідентичність і психологічна стать ми дійшли висновку, що їх можна вважати синонімічними. Зокрема в праці О.Г. Лопухової психологічна стать особистості визначається як певна статева ідентичність особистості, котра досягається в процесі статевої ідентифікації (ототожнення себе з представниками своєї статі) [7].

Таким чином, гендерна ідентичність - це реальне оволодіння особистістю чоловічою чи жіночою роллю, досягнення певного рівня статевої самосвідомості й ідентифікації. Однією 3 основних характеристик гендерної ідентичності є засвоєння статевої ролі (способу поведінки людей залежно від їхніх позицій у статевій диференціації), а також розвиток гендерної самосвідомості (усвідомлення своєї схожості й відмінності із представниками своєї статі на відміну від протилежної).

Аналіз зарубіжних психологічних досліджень гендерної ідентичності, показав, що існує кілька теорій ii формування. У психоаналітичній теорії ідентифікації підкреслюється роль емоцій і наслідування та передбачається, що дитина несвідомо імітує поведінку представників своєї статі, насамперед батьків, місце яких вона хоче зайняти. У біхевіоринальній теорії статевої типізації надається вирішальне значення механізмам підкріплення; дівчаткам за фемінну поведінку й для хлопчиків - навпаки. Теорія соціального навчання (моделювання) у формуванні гендерної ідентичності визнає найважливішими батьківські моделі, які дитина намагається наслідувати і підкріплення, що дають дитині батьки. У когнітивно-генетичній теорії самокатегоризації підкреслюється пізнавальний бік цього процесу: дитина спочатку засвоює статеву ідентичність, виокремлюючи себе як «хлопчика» та «дівчинку», а потім намагається узгодити свою поведінку з тим, що здається їй відповідним такому розподілу.

Численними дослідженнями [13-16 ] доведено, що мужність і жіночність не протиставляються одна одній, а людина 3 характеристиками, які чітко 
відповідають іiі статі, виявляється малопристосованою до життя і відповідно, більше піддається впливу стресогенних факторів. Так, низькомаскулінні жінки й високофемінінні чоловіки відзначаються безпорадністю, пасивністю, тривожністю, схильністю до депресії. Високомаскулінні жінки й чоловіки характеризуються труднощами у встановленні та підтримці міжособистісних контактів, що негативно позначається на професійній діяльності вчителя. Разом 3 тим виявлений зв'язок андрогінії з високою самоповагою, здатністю бути наполегливим, мотивацією до досягнень, ефективним виконанням батьківської ролі, внутрішнім відчуттям благополуччя. Андрогінна особистість має багатий набір статеворольової поведінки й гнучко використовує його залежно від соціальних ситуацій, які динамічно змінюються.

Однак, згладжування відношення «чоловічого-жіночого» у свідомості й поведінці людини містить у собі певну загрозу втрати позитивної соціальної ідентичності, тому що є інститути (родини, школи, ЗМI, ринки праці), які продовжують закріплювати статево рольові розпорядження. Таким чином, проблема симетричного конструювання жіночого й чоловічого в культурі вимагає значних змін у структурі суспільних інститутів, зокрема освітніх організацій, які є інститутом соціалізації особистості, в тому числі гендерної.

Таким чином, гендерна ідентичність $\epsilon$ однією із найважливіших психологічних характеристик людини, показником психічного здоров'я, умовою єдності особистісних проявів. Вона значно впливає на формування та структурування самовизначення в особистісному та соціально-психологічному розумінні. Гендерна ідентичність студентів $\epsilon$ особистісною детермінантою їхньої навчальної і професійної діяльності. Однак, соціально-психологічні фактори можуть зумовлювати і негативні їі прояви, виступаючи стресогенним чинником (Берн Ш. М.) [2]. До стресогенних особливостей гендерної ідентичності особистості студента, на наш погляд, можна віднести: труднощі перебігу процесів гендерної соціалізації і поетапного формування гендерної ідентичності.

Виклад основного матеріалу. Опитування проводилось у січні 2019 року. В ньому взяли участь 50 студентів, що поєднують навчальний процес із трудовою діяльністю віком від 19-ти до 21-го року. Серед них: 25 дівчат і 25 юнаків - студенти психолого-педагогічного факультету соціальнопедагогічного інституту «Педагогічна академія» та студенти Кіровоградського національного технічного університету стаціонарної та заочної форми навчання.

Опитувальник, що $\epsilon$ авторською розробкою, складався 315 запитань. Ставилось за мету дослідити самооцінку студентів та прояви стресу.

В процесі психологічного аналізу отриманих даних, ми з'ясувалили, що найчастіше як чоловікам, так і жінкам удається поєднувати трудову діяльність та навчання, не зважаючи на труднощі, що виникають внаслідок цього.

Окрім цього, слід зазначити, що у процесі поєднання трудової діяльності й навчання, виявляється, що навчання переважній кількості респондентів заважає (54\%), ніж допомагає (40\%). Водночас, слід зауважити, що жінки більше 
впевнені, що навчання негативно впливає на трудову діяльність, ніж чоловіки. Ймовірно, це пов'язано з більшою відповідальністю жінок щодо навчання ніж чоловіків.

У наступних питаннях ми з'ясовували причини, через які, студенти мають поєднувати навчання й трудову діяльність. Домінуючим чинником поєднання навчання із трудовою діяльністю як чоловіки так i жінки визначають недостатній матеріальний рівень батьків (22\% жінок й 18\% чоловіків). Окрім цього важливим фактором поєднання навчання із працею виступає створення власної сім’ї та необхідність їі забезпечувати (18\% жінок й 14\% чоловіків).

Втім, на питання щодо можливостей оптимально вирішувати проблеми, що спричинили поєднання трудової діяльності з навчанням, думки розподілилися. Так, чоловіки-студенти вважають, що саме зараз вони спроможні вирішувати власні матеріальні проблеми (20\% чоловіків та 4\% жінок), відчувають незалежність та самостійність (22\% чоловіків, $6 \%$ жінок). Водночас, жінки більш схиляються до того, що саме необхідність працювати створює матеріальні ускладнення (20\% жінок, 2\% чоловіків), більше того, проблеми виникають як у професійній сфері, так і у навчальній діяльності (18 \% жінок, 4\% чоловіків).

Хоча, як відмічають респонденти, праця допомагає навчанню, тому що додає відповідальності й усвідомленого смислу навчальної діяльності. Жінки зауважують, що праця поширює їхнє світосприйняття, внаслідок цього i здійснює позитивний вплив на навчальну діяльність.

Більшість опитаних ( 68\%) вважають, що якісну освіту можна отримати лише під час стаціонарного навчання. Гендерна ознака у цьому випадку майже не має значення. Тобто як жінки, так і чоловіки за сприятливих умов обрали би навчання.

За висловленнями жінок, їхня статева належність сприяє кар'єрному зростанню, а на думку чоловіків - створює їм перешкоди й додаткові навантаження.

Варто звернути увагу, що більшість студентів (63\%) визначились в тому, що їхня статева ознака не впливає на навчання й оцінювання їхніх знань викладачами. На думку опитаних, як чоловіків так і жінок їм вдається поєднувати працю 3 навчанням за умов власної організованості, тому вони не відчувають потребу у обмеженні лише однією альтернативою - працею чи навчанням.

Втім, як вважають респонденти обох статей їхня нова соціальна роль, пов'язана 3 поєднанням навчання із працею досить позитивно сприймаються однолітками.

Також важливо наголосити на тому, що батьки опитаних також позитивно оцінюють намагання доньки чи сина опановувати трудову діяльність, тому що це сприяє їхній відповідальності й бажанню самостійно вирішувати власні матеріальні проблеми.

Динаміка певним чином змінюється, якщо аналізувати жіночі й чоловічі вибори. Цікаво, що найчастіше жінки позитивно сприймають те, що іхній 
обранець працює, тобто є самостійним та незалежним від батьків (78\%). Навпаки, чоловіки (61\%) не завжди позитивно сприймають те, що жінка працює, бо вважають, що незалежність їй шкодить.

Як чоловіки так і жінки 3 гордістю сприймають власну можливість поєднувати працю з навчанням, тому що це свідчить про їхню незалежність та самостійність.

Водночас, важливим моментом є той факт, що більшість респондентів жінок (89\%), працюють не за спеціальністю, за якою навчаються. Половина (50\%) опитаних розчарувалися в обраній професії і бажають у подальшому реалізовуватись у інших сферах. Переважно чоловіки вважають, що трудовий досвід надав можливість з'ясувати випадковість й невірність обраного професійного шляху й навчального закладу.

Значна більшість $(80 \%)$ опитаних, що поєднують трудову діяльність із навчанням відчувають себе щасливими, тобто вони дійсно задоволені власним вибором. Чоловіки більше задоволені, ніж жінки. Жіноча частина опитаних усе ж таки вважають себе нещасливими. Отже, не дивлячись на те, що жінки говорять, що ніби то вони задоволені можливістю поєднувати працю 3 навчанням, за особливістю їхнього емоційного стану (що пов'язано з відчуттям щастя) можна зробити висновок, що вони не задоволені необхідністю поєднувати навчання із працею. Слід зазначити, що жінки й чоловіки, що поєднують трудову діяльність із навчанням вважають себе дорослими. Водночас, переважно чоловіча стать, сприймає себе дорослими, сформованими особистостями, ніж жіноча.

Висновки. На основі теоретико-емпіричного аналізу результатів дослідження робимо наступні узагальнення:

1. ауважимо, що гендерна ідентичність $\epsilon$ однією 3 найважливіших психологічних характеристик людини, показником психічного здоров'я, умовою єдності особистісних проявів. Якщо виходити з таких засад, то стає зрозумілим, що гендерна ідентичність студентів $\epsilon$ особистісною детермінантою їхньої навчальної й професійної діяльності. Оскільки соціально-психологічні фактори можуть зумовлювати й негативні iї прояви, виступаючи стресогенним чинником, що виявляється у труднощах перебігу процесів гендерної соціалізації і поетапного формування гендерної ідентичності.

2. Більшість студентів задоволені тим, що можуть у даному віці поєднувати навчання 3 роботою, але юнаки позитивніше сприймають можливість такого поєднання; натомість дівчата розглядають таке поєднання як вимушену ситуацію, якої ладні уникнути.

3. Загалом не можливо визначити однозначний вплив такого поєднання на емоційний стан студентів. Якщо участь у трудовому процесі успішна, то позитивним є і ставлення до іiі поєднання з навчанням. Якщо ж негативна, тобто трудова діяльність виступає вимушеним кроком, то негативно сприймається i необхідність водночас навчатися. Показово, що переважна більшість респондентів, які негативно сприймають потребу і працювати, і при 
цьому навчатися - дівчата.

4. За результатами опитування випливає, що юнацтву в даному віці легше працювати, аніж навчатись. Отже, ми підтвердили зазначене положення, яке запропонували Б.С.Волков, Н.В.Волкова, що всі студенти, які працюють відчувають себе дорослими. Але ми з'ясували, що це відчуття мають і ті студенти, які негативно ставляться до трудової діяльності. Тому, виникнення такого відчуття можна розглядати як одне зі свідчень особистісного зростання. Ця проблема вимагає детальнішого дослідження, до якого ми і маємо намір звернутися у подальшому.

\section{Jimepamypa:}

1. Антонова Н.В. Проблема личностной идентичности в интерпретации современного психоанализа, интеракционизма и когнитивной психологии // Вопросы психологии. - 1996. №1. - С. 131-143.

2. Берн Ш. М. Гендерная психология. - СПб.: Нева, 2001. - 320 с.

3. Ильин Е. П. Дифференциальная психофизиология мужчины и женщины. - СПб.: С.Питербург, 2003. - 544 с.

4. Карамушка Л.М., Зайчикова Т.В. Синдром «професійного вигорання» у вчителів: гендерні аспекти. - К.: Міленіум, 2003. - 40 с.

5. Кон И.С. Психология половых различий //Вопросы психологии. - 1981. - № 2. - С 47-57.

6. Коломинский Я.Л., Мелтсас М.Х. Ролевая дифференциация пола у дошкольников//Вопросы психологии.- 1985. -№3. -С. 165-171.

7. Лопухова О.Г. Психологический пол личности: адаптация использование женщиной своего тела. - СПб.: Б.С.К., 1997. С.43-45.

8. Практикум по гендерной психологии / Под ред. И.С. Клециной. - СПб.: С.Питербург, 2003. - 480с.

9. Романов И.В. Особенности половой идентичности подростков // Вопросы психологии. - 1997. - №4. - С. 39-47.

10. Словарь гендерных терминов / Под ред. А.А. Денисовой / Региональная общественная организация «Восток-Запад: Женские Инновационные Проекты». - М.: Информация XXI век, 2002. - 256 с.

11. Чекалина А.А. О формировании Я мальчика и Я девочки - мужчины и женщины // Мир психологии. - 2002. №2. - С. 110-117.

12. Эриксон Э. Идентичность: юность и кризис. - М.: Прогресс, 1996. - 344 с.

13. Archer, S.L. Identity and the choice of social roles // New Directions for Child Development, 1985, v.30, p. 79-100.

14. Bern, S.L. The measurement of psychological androgyny / Journal of Consulting and Clinical Psychology, 1974, №42, pp. 155-162.

15. Communication and sex-role socialization / Edited by C. Berryman-Fink, D. Ballard ReiscVi, L.H. Newman. Garland Publishing, inc. New York \& London, 1993. pp.22-27.

16. Spense, J.T., Helmreich, R.L. Masculinity and feminity: Their psychological dimensions, correlates, and antecedents / By J.T. Spense and R.L. Helmreich. - University of Texas press, 1979.-189.

\section{References:}

1. Antonova, N.V (1996). Problema lichnostnoj identichnosti v interpretacii sovremennogo psihoanaliza, interakcionizma i kognitivnoj psihologii [The problem of personal identity in the interpretation of modern psychoanalysis, interactionism and cognitive psychology]. Voprosy psihologii - Questions of psychology, 1, 131-143 [in Russian].

2. Bern, Sh. M. (2001). Gendernaja psihologija [Tender psychology]. SPb .: Neva [in Russian]. 
3. Ilyin, E.P (2003). Differencial'naja psihofiziologija muzhchiny i zhenshhiny [Differential psychophysiology of man and woman]. SPB .: St. Petersburg [in Russian].

4. Karamushka, LM, Zaychikova, T.V 92003). Sindrom «profesijnogo vigorannja» u vchiteliv: genderni aspekti [Teacher burnout syndrome in teachers: gender aspects]. - K .: Millennium [in Ukrainain].

5. Con, I.S. (1981). Psihologija polovyh razlichij [Psychology of gender differences]. Voprosy psihologii - Questions of psychology, 2, 47-57 [in Russian].

6. Kolominsky, J.L, Meltsas, M.H (1985). Rolevaja differenciacija pola u doshkol'nikov [Role differentiation of sex in preschoolers]. Voprosy psihologii - Questions of psychology, 3, 165-171 [in Russian].

7. Lopukhova, O.G (1997). Psihologicheskij pol lichnosti: adaptacija ispol'zovanie zhenshhinoj svoego tela [Psychological gender of the person: adaptation of use by the woman of the body]. SPb .: B.S.K [in Russian].

8. Clecina, . I.S. (2003). Praktikum po gendernoj psihologii [Workshop on Gender Psychology]. SPB .: St. Petersburg [in Russian].

9. Romanov, I.V (1997). Osobennosti polovoj identichnosti podrostkov [Peculiarities of sexual identity of adolescents] Voprosy psihologii - Questions of psychology, 4, 39-47 [in Russian].

10. Denisova, A.A. (2002). Slovar' gendernyh terminov [Dictionary of gender terms ] M .: Information of the XXI century [in Russian].

11. Chekalina, A.A. (2002). O formirovanii Ja mal'chika i Ja devochki - muzhchiny i zhenshhiny [On the formation of I boy and I girl - men and women]. Mir psihologii - World of Psychology, 2, 110-117 [in Russian].

12. Erickson, E.(1996). Identichnost': junost' i krizis [Identity: youth and crisis]. M .: Progress [in Russian].

13. Archer, S.L. Identity and the choice of social roles // New Directions for Child Development, 1985, v.30, p. 79-100.

14. Bern, S.L. The measurement of psychological androgyny / Journal of Consulting and Clinical Psychology, 1974, №42, p. 155-162.

15. Communication and sex-role socialization / Edited by C. Berryman-Fink, D. Ballard ReiscVi, L.H. Newman. Garland Publishing, inc. New York \& London, 1993.pp.22-27.

16. Spence, J.T., Helmreich, R.L. Masculinity and feminity: Their psychological dimensions, correlates, and antecedents / By J.T. Spense and R.L. Helmreich. - University of Texas press, 1979.p-189. 